\author{
Olga Kowalczyk \\ Uniwersytet Ekonomiczny we Wrocławiu
}

\title{
Ćwierć wieku reformowania systemu zabezpieczenia społecznego osób niepełnosprawnych w Polsce - wybrane aspekty
}

DOI: $10.19195 / 1643-0328.24 .5$

Słowa kluczowe: niepełnosprawność, zabezpieczenie społeczne, zatrudnienie, usługi opiekuńcze

\section{Wprowadzenie}

Zabezpieczenie społeczne jest podstawowym narzędziem stosowanym przez państwo $\mathrm{w}$ realizacji jego funkcji socjalnej ${ }^{1}$. Stopień ingerencji państwa $\mathrm{w}$ politykę społeczną jest sprawą o dużym znaczeniu, ponieważ zmniejszenie roli państwa będzie oznaczało mniejszy udział wydatków społecznych w PKB, mniejsze zaangażowanie publicznych podmiotów w dostarczaniu usług społecznych, pozbawienie rodziny „starszego brata” zapewniającego bezpieczeństwo socjalne. Można uznać, że we wszystkich krajach kształt realizowanej polityki społecznej zależy przede wszystkim od konstrukcji systemu zabezpieczenia społecznego - może on być różny w zależności od kształtu całego modelu wyznaczającego angażowanie się państwa w zaspokajanie potrzeb społecznych ${ }^{2}$.

W klasycznej literaturze przedmiotu system rehabilitacji osób niepełnosprawnych jest wymieniany jako jeden z elementów zabezpieczenia społecznego ${ }^{3}$. Stanisława Golinowska natomiast proponuje nazywać systemem zabezpieczenia społecznego osób niepełnosprawnych rozwiązania instytucjonalne stosowane w celu zapewnienia tym osobom środków do życia w sytuacji, gdy nie mogą tego uczynić samodzielnie, ponieważ ich zdolność do pracy jest ograniczona ${ }^{4}$. Proponuję rozszerzyć cel tego systemu — oprócz

${ }^{1}$ Chodzi o zaspokajanie przez państwo potrzeb uznanych za społecznie ważne, tworzenie określonego porządku społecznego. Sposobów definiowania funkcji socjalnej państwa jest wiele; zob. np. L. Dziewięcka-Bokun, J. Mielecki, Wybrane problemy polityki społecznej, Wrocław 1997, rozdz. 7.

2 Zob. np. M. Księżopolski, Wspólnie czy osobno. Rozważania o polityce społecznej, Warszawa 2013, s. 54-73.

3 Polityka społeczna, red. A. Rajkiewicz, Warszawa 1979, s. 435-436.

${ }^{4}$ S. Golinowska, Zabezpieczenie społeczne osób niepetnosprawnych $w$ Polsce i w innych krajach, Warszawa 2001, s. 12. 
dostarczania świadczeń pieniężnych chodzi także o dostęp do usług zapewniających możliwość społecznej aktywności (pracy, nauki, sportu, samodzielnego życia). W takim systemie wyróżnić można trzy najważniejsze elementy: wspieranie zatrudnienia, zapewnienie świadczeń ubezpieczeniowych w sytuacji ryzyka, jakim jest niezdolność do pracy, oraz pomoc społeczną jako ważny instrument polityki społecznej, uzupełniający pozostałe ${ }^{5}$.

Tym trzem elementom systemu zabezpieczenia społecznego poświęcone jest niniejsze opracowanie. Zostanie tu przeprowadzona syntetyczna analiza wspieranego zatrudnienia, wskazane będą wybrane aspekty systemu rentowego, który czeka na dostosowanie do nowego systemu emerytalnego, oraz omówione niektóre aspekty opieki długoterminowej - świadczenia dostępne dla członków rodzin osób niesamodzielnych ${ }^{6}$. Celem artykułu jest próba oceny dokonanych reform w zakresie stosowanych instrumentów polityki społecznej na rzecz osób niepełnosprawnych, zapisywanych w różnych aktach prawnych w wymienionym zakresie.

\section{Podstawowe reformy z lat dziewięćdziesiątych XX w.}

Po ponad 25 latach funkcjonowania tak zwanego systemu kwotowego w zatrudnianiu osób niepełnosprawnych, dokonaniu ponad 40 nowelizacji ustawy mającej swój początek

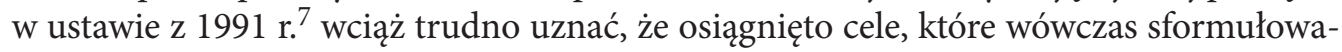
no: przede wszystkim doprowadzenie do otwarcia rynku pracy na osoby niepełnosprawne. Likwidacja tzw. spółdzielczości inwalidzkiej, kojarzonej z gospodarką socjalistyczną, wzorowanie się na rozwiązaniach stosowanych u zachodniego sąsiada miały temu sprzyjać. Przyjęto też, że celem będzie ograniczanie zatrudnienia chronionego i tworzenie zachęt do zwiększania tzw. zatrudnienia dotowanego na otwartym rynku pracy.

W ustawie z 1991 r. wprowadzono obowiązek zatrudniania pracowników niepełnosprawnych w firmach co najmniej pięćdziesięcioosobowych (czyli 7\% załogi). Jeśli taki zakład zatrudniał ustawową liczbę niepełnosprawnych, przyznawano mu ulgę w podatku dochodowym w wysokości równej osiągniętemu wskaźnikowi, przy czym $50 \%$ tych ulg zakład musiał przekazać do nowo utworzonego funduszu celowego, przeznaczonego na wspieranie zatrudnienia osób z niepełnosprawnościami - PFRON. Jednocześnie wprowadzono możliwość korzystania z dotacji do wynagrodzeń, składek ubezpieczeniowych, refundacji nowo utworzonych miejsc pracy dla niepełnosprawnych pracowników pod warunkiem zatrudniania ich przez co najmniej 3 lata. Ważną nowością zawartą w omawianym akcie prawnym było wprowadzenie pośrednictwa pracy dla osób z niepełnosprawnościami do rejonowych biur pracy. Na zakłady pracy nałożono obowiązek zatrudniania tych, którzy utracili zdolności do wykonywania pracy na dotychczasowym

\section{${ }^{5}$ Ibidem.}

${ }^{6}$ Ze względu na objętość artykułu nie omówiono tutaj wszystkich świadczeń dostępnych dla osób niepełnosprawnych.

${ }^{7}$ Ustawa z dnia 9 maja 1991 r. o zatrudnieniu i rehabilitacji zawodowej osób niepełnosprawnych (Dz.U. $\mathrm{Nr} 46 / 1991)$. 
stanowisku w wyniku wypadku przy pracy lub choroby zawodowej w danym zakładzie, pod groźbą wysokiej kary - wpłaty na PFRON w wysokości czterdziestokrotnego przeciętnego wynagrodzenia ${ }^{8}$. Istniejącą wcześniej spółdzielczość inwalidzką zamieniono na zakłady pracy chronionej, uprzywilejowane wobec otwartego rynku głównie poprzez zwolnienia od płacenia podatków, które miały być naliczane i część z nich miała trafiać do Zakładowego Funduszu Rehabilitacji. Na mocy ustawy mogły być tworzone Warsztaty Terapii Zajęciowej, nowe $\mathrm{w}$ polskich warunkach placówki przeznaczone przede wszystkim dla osób z ciężkimi formami niepełnosprawności ${ }^{9}$.

W 1997 r. uchwalono zasadniczo nową ustawę o rehabilitacji zawodowej i społecznej oraz zatrudnianiu osób niepełnosprawnych. W tym samym roku uchwalono też Kartę Praw Osób Niepełnosprawnych ${ }^{10}$. Ustawa wprowadziła nowy system orzekania o niepełnosprawności w celach nieubezpieczeniowych, co wiązało się również ze zmianą orzecznictwa w ZUS. Rozszerzono zakres działania ustawy do zakładów powyżej 25 osób i zmniejszono wskaźnik obowiązku zatrudniania niepełnoprawnych do 6\%, za ich niezatrudnianie wprowadzono karę w wysokości 40,65\% przeciętnego wynagrodzenia za każde miejsce pracy brakujące do wskazanego poziomu.

Na mocy tej ustawy możliwe jest tworzenie Zakładów Aktywności Zawodowej, nowej formy zatrudnienia - wspomaganego ${ }^{11}$, kierowanego do osób znacznie niepełnosprawnych przy wykorzystaniu usług między innymi trenerów pracy. Doprecyzowano uprawnienia pracodawców zatrudniających osoby niepełnosprawne i niepełnosprawnych pracowników w zakładach otwartego rynku i w Zakładach Pracy Chronionej. Zwiększyły się dochody PFRON oraz liczba zadań z niego finansowanych, oprócz tych związanych z zatrudnieniem pojawiły się też nowe, z zakresu rehabilitacji leczniczej i społecznej dorosłych oraz dzieci. Liczba zadań finansowanych ze środków PFRON i realizowanych na każdym szczeblu samorządu rozrosła się w kolejnych latach po reformie administracyjnej kraju z $1998 \mathrm{r}^{12}$. Jej celem była decentralizacja, upodmiotowienie obywateli, praktyczna realizacja społecznego modelu niepełnosprawności.

Na duże potrzeby w tym zakresie wskazywała między innymi wspomniana już Karta Praw Osób Niepełnosprawnych. W dokumencie tym, poza zdefiniowaniem prawa osób niepełnosprawnych do niezależnego i samodzielnego życia, wolnego od dyskryminacji, zawarto również katalog dziesięciu praw, wskazując tym samym najważniejsze obszary, w których niezbędne są intensywne działania. Konieczność taka wynikała z rozbieżności

${ }^{8}$ Ibidem.

${ }^{9}$ Od 1991 r. WTZ mogły być tworzone w zakładach pracy, np. ZPCH, od 1997 r. funkcjonują one jako odrębne jednostki organizacyjne. O. Kowalczyk, Rehabilitacja osób niepetnosprawnych - nowe rozwiązania, Wrocław 1993, s. 80-81.

10 Dz.U. Nr 123, poz. 776 i Uchwała Sejmu Rzeczypospolitej Polskiej z dnia 1 sierpnia 1997 r, (M.P. z 1997 r. Nr 50, poz 75.).

${ }^{11}$ Forma zatrudnienia o takiej nazwie nie istnieje w polskim prawie pracy, lecz jest ona znana i opisywana od lat w polskiej literaturze przedmiotu. Zob. np. E. Kryńska, K. Pater, Projekt. Zatrudnienie osób niepetnosprawnych. Perspektywy wzrostu, Warszawa 2013, s. 10, http://www.ipiss.com.pl (dostęp: 30 listopada 2016); Zatrudnienie wspomagane „eBIFRON” 2014, nr 2, https://www.pfron.org.pl/aktualnosci/szczegoly-aktualnosci/news/najnowsze-wydanie-ebifron/ (dostęp: 13 marca 2018).

12 Samorzad terytorialny. Teksty jednolite, Warszawa 1999. 
obserwowanych pomiędzy obowiązującym prawem stanowionym, tj. ogólnymi i szczegółowymi przepisami prawa, a faktyczną ich realizacją ${ }^{13}$.

Zasadnicze znaczenie dla funkcjonowania społecznego osób niepełnosprawnych miały także zmiany, jakie dokonały się w latach dziewięćdziesiątych XX w. w systemie ubezpieczeń społecznych. Przeprowadzono wspomnianą wcześniej r e for m ę o r z e c z n i c t w a, oddzielono orzekanie o niepełnosprawności w celach pozaubezpieczenowych (np. związanych z zatrudnieniem) od niezdolności do pracy w celach ubezpieczeniowych (rentowych). Wprowadzenie nowego instrumentu pod nazwą p r e w e n c j i r e n t o w e j i nowego rodzaju świadczenia ubezpieczeniowego w postaci renty szkoleniowej miało zachęcić osoby niepełnosprawne do wychodzenia z bierności zawodowej i podejmowania pracy ${ }^{14}$. Tak się jednak nie stało, o czym świadczy marginalny udział wydatków na renty szkoleniowe w ogóle wydatków na renty z tytułu niezdolności do pracy ${ }^{15}$. Próbowano racjonalizować wydatki ponoszone na finansowanie rent inwalidzkich, co oznaczało zmniejszenie liczby rent przyznawanych pod koniec lat dziewięćdziesiątych i później, pozwoliło to zmniejszyć udział rent z tytułu niezdolności do pracy w PKB z około 4\% w latach 1993-1994 do 3\% w 2000 i tylko 1,39\% w $2010 \mathrm{r}$. W kolejnych latach malała liczba rent przyznawanych z tytułu niezdolności do pracy, na niskim poziomie pozostawała ich stopa zastąpienia wynosząca w 2014 r. około $40 \%^{16}$.

Konstrukcja renty z tytułu niezdolności do pracy wciąż nawiązuje do formuły emerytury w starym systemie: jej biorcy po osiągnięciu wieku emerytalnego automatycznie powinni przechodzić do systemu emerytalnego, jeśli emerytura byłaby świadczeniem korzystniejszym ekonomicznie. Rodzi się pytanie: jaka będzie wysokość emerytur długotrwałych biorców rent $\mathrm{z}$ tytułu niezdolności do pracy? Czy ze względu na obowiązującą nową formułę emerytury - tzw. świadczenia o zdefiniowanej składce - zależnej głównie od wysokości zgromadzonego kapitału emerytalnego i czasu jego wypłacania, emerytury dotychczasowych biorców rent, ze względu na swą bardzo niską kwotę, prze-

13 Informacja o działaniach podejmowanych na rzecz realizacji postanowień uchwały Sejmu Rzeczypospolitej Polskiej z dnia 1 sierpnia 1997 r. „Karta Praw Osób Niepełnosprawnych”, Warszawa 2001 http://www. niepelnosprawni.pl/files/www.niepelnosprawni.pl/public/rozne_pliki/kartaprawON.pdf (dostęp: $13 \mathrm{marca}$ 2018); takie coroczne informacje znajdują się na stronie http://www.niepelnosprawni.gov.pl.

14 Nowelizacja ustawy o organizacji i finansowaniu ubezpieczeń społecznych uchwalona w czerwcu $1996 \mathrm{r}$. (Dz.U. Nr 100, poz. 46) oraz ustawa o emeryturach i rentach z FUS z 1998 r. (Dz.U. Nr 62, poz. 1118).

15 Zob.: Wydatki na świadczenia z ubezpieczenia społecznego związane z niezdolnością do pracy $w 2013$ r., http://www.zus.pl/documents/10182/39540/Wydatki+na+świadczenia+z+ubezpieczeń+społecznych+związa ne+z+niezdolnością+do+pra (dostęp: 13 marca 2018); Informacja o świadczeniach pieniężnych z FUS oraz o niektórych świadczeniach zabezpieczenia społecznego w 2015 roku, http://www.zus.pl/documents/10182/167627/ biul0414.pdf/b2401b7b-8ef4-41c8-9887-f75a9e4f92d1 (dostęp: 13 marca 2018).

16 N. Marska-Dzioba, Racjonalność wydatków publicznych przeznaczonych na integrację osób niepełnosprawnych w Polsce, Szczecin 2013, s. 183, 193; Informacja o wynikach kontroli wykonania budżetu państwa w 2014 r. w części 73 - Zakład Ubezpieczeń Społecznych oraz wykonania planów finansowych: Funduszu Ubezpieczeń Społecznych, Funduszu Emerytur Pomostowych, Funduszu Rezerwy Demograficznej i planu finansowego Zakładu Ubezpieczeń Społecznych - państwowej osoby prawnej, Warszawa 2015, https://www. nik.gov.pl/plik/id,11385.pdf (dostęp: 13 marca 2018). 
staną zastępować renty? Jeśli tak się stanie, to w niedługim okresie wielce prawdopodobny stanie się kryzys wypłacalności w systemie rentowym.

Na początku lat dziewięćdziesiątych przeprowadzono też zasadniczą reformę p o m o c y s p oł e c z n e j, a jej idee zapisano w ustawie z 1990 r. Ma to być pomoc skierowana ku usamodzielnieniu się, a nie opieka. Reformatorzy zwracali uwagę na konieczność odchodzenia od stosowania świadczeń pieniężnych na rzecz rozwoju usług ułatwiających życiowe usamodzielnienie się osób wymagających pomocy osób drugich w codziennym funkcjonowaniu. Usługi opiekuńcze świadczone w formie zakładowej i środowiskowej w ramach pomocy społecznej, wyłączonej wówczas z resortu zdrowia i przeniesione do resortu pracy i polityki społecznej, powinny uzupełniać świadczenia opieki długoterminowej realizowane w ramach ochrony zdrowia. Do tych zagadnień wypadnie powrócić w dalszej części opracowania.

\section{Efekty stosowanych instrumentów}

Na podstawie wielu badań terenowych i analizy danych statystycznych można dojść do wniosku, że niestety efektywność istniejącego w Polsce systemu udziałowego w zatrudnianiu osób z niepełnosprawnościami jest niewielka ${ }^{17}$. Przez cały okres jego funkcjonowania stopa zatrudnienia niepełnosprawnych pozostaje dużo niższa niż w większości krajów UE, w których wynosi ona od $20-40 \%{ }^{18}$.

W roku 2000 wskaźnik aktywności zawodowej osób niepełnosprawnych w wieku 15 lat i więcej wynosił 19,2 \%, a wskaźnik zatrudnienia - 15,7\% i na zbliżonym poziomie utrzymywały się one przez całą dekadę do 2010 r. i później.

Od 2011 r. kolejny raz zmieniono zasady dofinansowania dla pracodawców otwartego rynku zatrudniających niepełnosprawnych, zwiększając kwoty dopłat dla pracowników ze znacznym stopniem niepełnosprawności. Spowodowało to powolny wzrost zatrudnienia osób z cięższymi formami niepełnosprawności w ostatnich latach. Stopa zatrudnienia wszystkich niepełnosprawnych w wieku powyżej 16 lat według danych BAEL wynosiła w 2015 r. 14,9\%, a wskaźnik aktywności zawodowej oszacowany został na poziomie $16,7 \%{ }^{19}$.

Oba te wskaźniki były ponad trzy razy niższe niż dla ogółu ludności Polski. Oznacza to, że około jedna czwarta wszystkich rodzin w Polsce, w których żyją osoby nie-

17 Zob. np.: J. Jaworski, Praca dla osób niepetnosprawnych w zwalczaniu ich wykluczenia społecznego. Ocena polskiego systemu wspierania zatrudnienia osób niepetnosprawnych, Warszawa 2009, s. 136; E. Kryńska, K. Pater, op. cit.; M. Garbat, Zastosowanie modelu DMP w analizie rynku pracy osób z niepetnosprawnościa, „Polityka Społeczna” 2013, nr 8, s. 30; A. Barczyński, Realne bariery wstrzymujące aktywizację zawodowa niepetnosprawnych, [w:] Społeczne korzyści zatrudniania osób niepetnosprawnych, red. A. Barczyński, Warszawa 2008, s. 292-293; B. Kołaczek, Proponowane kierunki zmian dotychczasowego systemu wsparcia zatrudnienia osób niepełnosprawnych, „Polityka Społeczna” 2014, nr 8, s. 38; J. Oczki, Nierówności na rynku pracy w Polsce, [w:] Nierówności społeczne w Polsce, red. B. Kłos, J. Szymańczak, Warszawa 2014, s. 157.

${ }_{18}$ M. Garbat, op. cit., s. 25.

19 www.niepelnosprawni.gov.pl (dostęp: 30 listopada 2016). 
pełnosprawne, boryka się z problemem niskich dochodów. Zmniejszona dostępność do rent $\mathrm{z}$ tytułu niezdolności do pracy od drugiej połowy lat dziewięćdziesiątych oraz zbyt mała liczba miejsc pracy dla osób niepełnosprawnych musiały spowodować pogorszenie się sytuacji bytowej tej grupy społecznej. Odsetek osób w gospodarstwach domowych z osobami niepełnosprawnymi o wydatkach poniżej progu ubóstwa względnego wynosił w 2014 r. 16,2\%. Niepokojące są bardziej szczegółowe dane. Liczba gospodarstw domowych z osobami niepełnosprawnymi, w których wydatki znalazły się poniżej ustawowej linii ubóstwa w latach 2011-2014, znacząco wzrosła - z 6,6\% do 12,2\%. Najbardziej liczną grupę ubogich rodzin według tego kryterium stanowiły rodziny mające przynajmniej jedno dziecko z orzeczeniem o niepełnosprawności - było ich 26,6\% w 2014 r., a według linii relatywnej wskaźnik ten wynosił aż $29,9 \%$. Wśród rodzin z niepełnosprawną głową gospodarstwa domowego poniżej progu ubóstwa względnego było w 2014 r. 21,9\% ogółu tych rodzin, a na poziomie ubóstwa ustawowego $-14,6 \%{ }^{20}$. W szczególnie trudnej sytuacji ekonomicznej znajdują się samotne osoby niepełnosprawne, następnie pary z jedną osobą niepełnosprawną lub samotne matki z dzieckiem niepełnosprawnym ${ }^{21}$.

Co należy zrobić, aby poprawić ich sytuację? Wciąż podejmuje się badania mające znaleźć odpowiedź na pytanie, jak zwiększyć aktywność społeczną, szczególnie zawodową, osób z niepełnosprawnościami. Jak usuwać bariery istniejące w tym względzie? Najważniejsze $\mathrm{z}$ nich, wielokrotnie wskazywane $\mathrm{w}$ literaturze przedmiotu, to: związane $\mathrm{z}$ rynkiem pracy (mało ofert pracy, postawy pracodawców niechętne zatrudnianiu takich osób, często zmieniające się sposoby dofinansowania zatrudnienia osób niepełnosprawnych z różnym stopniem niepełnosprawności), postawy biorców rent (brak motywacji do pracy, niska samoocena, postawy roszczeniowe) oraz utrudnienia wynikające ze słabości oferty szkoleniowej (szkolenia wybierane według kryterium „niskiej ceny”, oderwane od praktyki i rzeczywistości rynku pracy, niedostosowane do potrzeb i możliwości osób niepełnosprawnych, często oddalone od ich miejsca zamieszkania, do których trudno dojechać) ${ }^{22}$.

20 Zob. tab. 1.10. Zasięg ubóstwa w gospodarstwach domowych z osobami niepełnosprawnymi prawnie [w:] Ubóstwo w Polsce w latach 2013-2014, „Studia i Analizy Statystyczne”, GUS, Warszawa 2015, https://stat. gov.pl. Ubostwo_w_polsce_w_latach_2013-2014.pdf (dostęp: 13 marca 2018).

${ }_{21}$ O. Kowalczyk, Jaka polityka społeczna wobec rodzin $z$ osobami niepetnosprawnymi w Polsce?, „Prace Naukowe UE we Wrocławiu" 2016, nr 438, s. 171.

22 Zob. np.: J. Petelczyc, P. Roicka, Wyniki badań zrealizowanych metoda IDI w powiatowych urzędach pracy, [w:] Rehabilitacja zawodowa. Stan aktualny i proponowane zmiany, red. G. Uścińska, A. Wilmowska-Pietruszyńska, Warszawa 2014, s. 251-253. Niska zatrudnieniowa efektywność szkoleń odnotowywana jest od lat w odniesieniu do ogółu szkoleń realizowanych jako instrument $w$ walce z bezrobociem. Aktywizację uznaje się za skuteczną, jeśli osoba bezrobotna znalazła zatrudnienie na wolnym rynku w ciągu trzech miesięcy od zakończenia aktywizacji i nie powróciła w tym czasie do rejestru bezrobotnych. W latach 2011-2013 tak rozumiana skuteczność staży wyliczona przez NIK wynosiła od 33\% do 39\%, a szkoleń od 18\% do 21\%. Po upływie roku od zakończenia aktywizacji wskaźniki skuteczności były jeszcze niższe: trwałość zatrudnienia dla nowo zatrudnionych po stażach wahała się w przedziale od $23 \%$ do $29 \%$, i od $12 \%$ do $17 \%$ po szkoleniach. Cyt. za: Informacja o wynikach kontroli. Skuteczność wybranych form aktywnego przeciwdziałania bezrobociu w niektórych województwach w 2014 roku, https://www.nik.gov.pl/plik/id,8905,vp,11060.pdf (dostęp: 13 marca 2018). 
Wielu ekspertów sformułowało swoje rekomendacje. Uczyniła to też NIK w raporcie o wynikach kontroli realizacji programów wspierających wzrost zatrudnienia, wymieniając znane $z$ literatury następujące formy wsparcia integracyjnego ${ }^{23}$ :

- dofinansowanie wynagrodzeń i składek na ubezpieczenie społeczne,

- promowanie samozatrudnienia,

- szkolenia,

- wsparcie przy poszukiwaniu pracy,

- zatrudnienie wspomagane.

Wszystkie te instrumenty istnieją w polskim ustawodawstwie. Które z nich są najskuteczniejsze, trudno powiedzieć. Wydaje się, że wiele jeszcze można by zrobić szczególnie $\mathrm{w}$ odniesieniu do samozatrudnienia, pośrednictwa pracy i zatrudnienia wspomaganego czy wykorzystywania w szerszym zakresie elastycznych form zatrudnienia.

Wiele badań wskazuje na niewykorzystywanie w praktyce instrumentów aktywizujących w ramach rehabilitacji zawodowej, które według ustawy miały być realizowane w samorządach ze środków PFRON. Środki te są przekazywane do samorządów według algorytmu. $Z$ perspektywy samorządu obowiązujący obecnie algorytm nie jest sprawiedliwy. Polega on na tym, że pod uwagę bierze się osoby zarejestrowane w Urzędzie Pracy, a nie liczbę osób niepełnosprawnych, jaka występuje na danym terenie. Ponadto nie uwzględnia się w nim dwóch bardzo ważnych grup wiekowych, które również są obejmowane wsparciem: dzieci i młodzieży do 18. roku życia oraz osób po 65 . roku życia ${ }^{24}$. Ze względu na niewystarczającą ilość środków wiele ustawowych zadań pozostaje niezrealizowanych. Na przykład w województwie dolnośląskim ze środków przekazywanych samorządom nie pokrywa się kosztów przystosowania miejsc pracy dla niepełnosprawnych. Prawie w ogóle (bo na poziomie 0,2\% ogółu środków - tylko w powiecie Wrocław w 2011 i 2012 r. $^{25}$ ) nie zatrudniano asystentów pracy, nie dotowano wynagrodzeń i nie refundowano składek na ubezpieczenia społeczne, nie dofinansowywano oprocentowania kredytów bankowych i nie pokrywano kosztów szkoleń organizowanych przez pracodawców. Jest to po części prawdopodobnie „usprawiedliwiane" tym, że podobne zadania finansowane są bezpośrednio przez PFRON w systemie obsługi dofinansowań i refundacji dostępnych dla przedsiębiorstw spełniających odpowiednie warunki ${ }^{26}$.

Aktywność zawodowa osób z niepełnosprawnościami jest, jak wiadomo, wypadkową bardzo wielu czynników o charakterze psychospołecznym i materialno-społecznym ze strony ich samych i otoczenia społecznego. O niektórych z nich już wspominano, nie można pominąć jeszcze jednego, niezwykle ważnego problemu - dostępności do reha-

${ }^{23}$ Ibidem, s. 44-45.

${ }^{24}$ Raport końcowy w ramach badania pt. Badanie realizacji przez samorzady powiatowe zadań ustawowych na rzecz osób niepetnosprawnych, https://www.pfron.org.pl/aktualnosci/szczegoly-aktualnosci/news/ raport-koncowy-z-badania-realizacji-przez-samorz (dostęp: 13 marca 2018).

${ }^{25}$ Według informacji dolnośląskiego oddziału PFRON było podobnie w latach zarówno wcześniejszych, jak i późniejszych.

26 O. Kowalczyk, Zatrudnienie i rehabilitacja zawodowa osób niepetnosprawnych $w$ Polsce $w$ kontekście praw społecznych - wybrane zagadnienia, „Ubezpieczenia Społeczne. Teoria i praktyka” 2015, nr 3, s. 17. 
bilitacji medycznej i nowoczesnego sprzętu ortopedycznego i rehabilitacyjnego. Permanentna reforma systemu ochrony zdrowia, brak jednoznacznie zdefiniowanego koszyka usług medycznych dostępnych w systemie publicznym i wiele innych organizacyjnych i finansowych problemów trawiących polską ochronę zdrowia, nie sprzyja zaspokajaniu w systemie publicznym zwiększonych potrzeb zdrowotnych osób z niepełnosprawnościami ${ }^{27}$. Ich niskie dochody zaś ograniczają dostęp na zasadach rynkowych do nowoczesnych technologii, kompensujących skutki niepełnosprawności.

W szczególnie trudnej sytuacji życiowej w całym okresie transformacji i obecnie znajdują się rodziny osób wymagających stałej opieki. Istniejące rozwiązania w zakresie opieki długoterminowej od lat poddawane są krytyce w literaturze przedmiotu ${ }^{28}$. Wspomniana podległość organizacyjno-finansowa pod dwa resorty: Ministerstwo Zdrowia i Ministerstwo Rodziny, Pracy i Polityki Społecznej placówek i usług opieki długoterminowej nie wydaje się dobrym rozwiązaniem. Wciąż brakuje miejsc w placówkach całodobowych podlegających resortowi zdrowia (np. Zakłady Opiekuńcze Lecznicze). Czas oczekiwania na miejsce $w$ nich $w$ wielu rejonach kraju wynosi ponad 2 lata ${ }^{29}$. Jak powszechnie wiadomo, dostępność do świadczeń medycznych nie spełnia społecznych oczekiwań, szczególnie trudna sytuacja występuje także w zakresie geriatrii i usług medycznych wobec niesamodzielnych osób starszych ${ }^{30}$.

Słabo rozwinięte są także usługi opiekuńcze (nie o charakterze medycznym) w środowisku zamieszkania, świadczone w ramach pomocy społecznej. Niskie kryterium dochodowe stosowane przez władze lokalne do przyznawania bezpłatnych usług opiekuńczych w dużym stopniu ograniczyło dostęp do nich biorcom rent i emerytur, których wysokość była i jest często od tego kryterium wyższa. Jest jednak wysoka nie na tyle, by pozwolić skorzystać z usług opiekuńczych na zasadach komercyjnych.

Wiele czynników decyduje o skali udzielania osobom niesamodzielnym pomocy usługowej w danym regionie. Na podstawie dostępnych danych można zauważyć, że liczba korzystających z usług opiekuńczych wzrasta wraz z udziałem liczby seniorów w gminie. Przeważają gminy, które udzielają usług opiekuńczych dosłownie kilku lub kilkuna-

${ }^{27}$ Dotyczy to np. specyficznych usług stomatologicznych dla osób z porażeniem mózgowym, dostępności gabinetów ginekologicznych dla kobiet mających problemy z poruszaniem się, porozumiewania się w placówkach służby zdrowia osób głuchoniemych, oznakowania lekarstw dla osób niewidomych. O niektórych z nich można przeczytać w: E. Ciaputa, A. Król, M. Warat, Genderowy wymiar niepetnosprawności. Sytuacja kobiet z niepetnosprawnościami wzroku, ruchu, słuchu, [w:] Polscy niepetnosprawni. Od kompleksowej diagnozy do nowego modelu polityki społecznej, red. B. Gąciarz, S. Rudnicki, Kraków 2014, s. 275-335.

${ }^{28}$ Na przykład: System wsparcia osób starszych w środowisku zamieszkania. Przegląd sytuacji. Propozycja modelu, red. B. Szatur-Jaworska, P. Błędowski, Warszawa 2016, http://www.rpo.gov.pl (dostęp: 10 czerwca 2017).

29 Tak jest np. we Wrocławiu według informacji pracowników Miejskiego Centrum Usług Socjalnych.

${ }^{30}$ Zob. np.: Świadczenie pomocy osobom starszym przez gminy i powiaty, https://www.nik.gov.pl/aktualnosci/nik-o-swiadczeniu-pomocy-osobom-starszym.html (dostęp: 13 marca 2018); Opiekunowie rodzinni osób starszych - problemy, potrzeby, wyzwania dla polityki społecznej. Raport z badania, oprac. M. Szlązak, A. Piłat, J. Sarata, Kraków 2015. 
stu niesamodzielnym seniorom. 14\% przedstawicieli badanych gmin w województwie dolnośląskim zadeklarowało, że nikt w 2014 r. nie skorzystał z usług opiekuńczych ${ }^{31}$.

W związku z trudnością uzyskania pomocy z „zewnątrz” w opiece nad osobami zależnymi członkowie ich rodzin zmuszani są często do rezygnacji z pracy. Aktualnie — w 2017 r. - możemy mówić o istnieniu w Polsce trzech typów świadczeń powiązanych ze sprawowaniem opieki nad osobami niesamodzielnymi: świadczeniu pielęgnacyjnym, specjalnym zasiłku opiekuńczym, a także zasiłku dla opiekuna ${ }^{32}$. Wysokość tych świadczeń jest zróżnicowana. Świadczenie pielęgnacyjne adresowane do pozostających poza zatrudnieniem rodziców i opiekunów osób wymagających stałej opieki, które stały się niepełnosprawne jeszcze w okresie dzieciństwa (przed 18. rokiem życia lub przed 25. rokiem, jeśli do tego czasu kontynuowały naukę), wynosi — po serii podwyżek — od 1 stycznia 2017 r. 1400 zł netto. Jego wysokość jest dostosowana do płacy minimalnej i waloryzowana o wskaźnik wzrostu minimalnego wynagrodzenia. Jest ono także objęte oskładkowaniem z tytułu ubezpieczenia emerytalno-rentowego i zdrowotnego, które za opiekuna uiszcza organ wypłacający świadczenie. Dostęp do niego jest zarezerwowany dla opiekunów, na których ciąży obowiązek alimentacyjny wobec podopiecznego oraz dla tych, którzy pozostają całkowicie poza zatrudnieniem i nie pobierają któregoś ze świadczeń o charakterze emerytalno-rentowym. By uzyskać tego typu pomoc, nie jest konieczne poddanie się weryfikacji kryterium odpowiednio niskiego dochodu.

W dużo trudniejszej sytuacji ekonomicznej znajdują się opiekunowie dorosłych osób niesamodzielnych. Dla nich przewidziane jest jedno z dwóch wspomnianych już świadczeń: specjalny zasiłek opiekuńczy bądź zasiłek dla opiekuna. Ich wysokość wynosi 520 zł. Pierwsze z wymienionych świadczeń adresowane jest do tej części opiekunów, którzy wcześniej posiadali uprawnienia do świadczenia pielęgnacyjnego, ale utracili je w 2013 r., kiedy to wprowadzono przepisy różnicujące status opiekunów według kryterium wieku, w jakim była osoba podopieczna w momencie, gdy utraciła samodzielność. Kryterium dochodowe, jakie trzeba spełnić, by go otrzymać, w 2017 r. ustalone jest na poziomie $764 \mathrm{zł}$ na osobę w gospodarstwie domowym ${ }^{33}$. W wypadku zasiłku dla opiekuna, istniejącego od 2014 r., kryterium dochodowe nie obowiązuje. Wynika z tego, że poza dostępem do tych świadczeń może znajdować się duża grupa rodzin mających nieco wyższe dochody (np. z powodu prawa do renty z tytułu niezdolności do pracy lub emerytury osoby zależnej), lecz z pewnością pod znakiem zapytania pozostaje ich bezpieczeństwo socjalne.

31 Dostępność wsparcia środowiskowego dla osób starszych w perspektywie przedstawicieli gmin województwa dolnośląskiego. Analiza i zalecenia, Warszawa 2016, https://www.rpo.gov.pl/sites/default/files/Dostępność\%20wsparcia\%20środowiskowego\%20dla\%20osób\%20starszyc (dostęp: 13 marca 2018).

32 Ustawa z dnia 28 listopada 2003 r. o świadczeniach rodzinnych, Dz.U. z 2015 r. poz. 114 z późn. zm.; ustawa z dnia 4 kwietnia 2014 r. o ustaleniu i wypłacie zasiłków dla opiekunów, Dz.U. z 2014 r. poz. 567.

33 http://www. mpips.gov.pl (dostęp: 30 kwietnia 2017). 
Do opisanego stanu rzeczy należy dodać, że wraz z brakiem prawa do któregoś ze świadczeń powiązanych ze sprawowaniem opieki nie jest odprowadzana za opiekunów składka na ubezpieczenie emerytalno-rentowe ${ }^{34}$, co zagraża ich bezpieczeństwu socjalnemu w przyszłości.

\section{Podsumowanie — najważniejsze wyzwania}

Polityka społeczna wobec osób niepełnosprawnych i ich rodzin powinna być systemem celowych i spójnych rozwiązań podejmowanych w praktyce przez różne polityki publiczne. Obecnie mamy do czynienia raczej z rzeczywistością „Polski resortowej”, w której współpraca międzyresortowa jest niezwykle trudna. Sprawami osób niepełnosprawnych zajmuje się wiele podmiotów publicznych i społecznych, często powielając swoje działania wobec tych samych adresatów. Jednocześnie pozostaje wiele „pustych pól”, na przykład brakuje łatwo dostępnej w środowisku zamieszkania informacji na temat przysługujących uprawnień, skutecznego pośrednictwa pracy odpowiadającego na potrzeby pracodawców i pracobiorców, usług opiekuńczych i pomocy osobistej.

Wiele badań prowadzonych w różnych krajach na przestrzeni ostatnich kilku dekad pokazuje, że rozwój środowiskowych usług opiekuńczych wobec osób niepełnosprawnych wspierających rodziny w pełnieniu funkcji opiekuńczych nad osobami niesamodzielnymi jest koniecznością. Dobrym przykładem są Niemcy, w których od 1994 r. istnieje powszechne ubezpieczenie pielęgnacyjne w ramach ubezpieczenia zdrowotnego (składka wynosi 2,35-2,6\% podstawy wymiaru, za pracowników o niskich dochodach płacą ją władze lokalne). Jak dotąd, jest to instytucja samofinasująca się, w skali ogólnokrajowej około 3\% ubezpieczonych jest świadczeniobiorcami usług w sytuacji niesamodzielności.

W Polsce podobne rozwiązania są wciąż słabo dostępne, ponoszone w związku z tym koszty w skali makrospołecznej nie są do końca policzone, bo nie uwzględniają na przykład tzw. kosztów zaniechania i utraconych korzyści, które mogłyby wyniknąć z aktywności społecznej osób ciężko niepełnosprawnych i ich nieformalnych opiekunów. Potrzebne są usługi opiekuńcze świadczone w sposób tradycyjny na terenie mieszkania osób niesamodzielnych i w postaci osobistej asystencji, wychodzącej poza jego obszar, ułatwiające aktywizację. Zawód asystenta osoby niepełnosprawnej już od kilku lat istnieje w naszym kraju, lecz najczęściej usługi asystenckie oferowane są w ramach grantu realizowanego przez jakiś podmiot samorządowy lub NGS, finansowanego ze środków europejskich. Jest to zatem okazjonalna dostępność do usług świadczonych sporadycznie, niemająca charakteru systemowego.

Aby móc skorzystać w szerszej skali z dobrych praktyk innych krajów w zakresie wspierania osób niepełnosprawnych i ich rodzin, należy odejść od stereotypowego traktowania polityki społecznej jako jedynie kosztu i obciążenia dla gospodarki, potrzebne

\footnotetext{
${ }^{34}$ Za biorców tych trzech świadczeń opiekuńczych odprowadzana jest składka jak od minimalnego wynagrodzenia, co także nie zabezpiecza im w przyszłości emerytury w godnej wysokości.
} 
jest myślenie o racjonalnym gospodarowaniu publicznymi środkami, zmianie ich struktury, należy rozliczać podmioty korzystające z publicznych środków nie za sam fakt podejmowania jakichś działań na rzecz słabszej grupy społecznej, lecz za uzyskane tą drogą rezultaty. Nie jest to łatwe i wciąż niestety rzadko stosowane.

Członkostwo w UE zobowiązuje do zapewnienia określonego poziomu bezpieczeństwa socjalnego wszystkim obywatelom. Najważniejszym aktem prawnym zobowiązującym państwa członkowskie UE do podejmowania konkretnych przedsięwzięć ułatwiających codzienne społeczne uczestnictwo osobom $\mathrm{z}$ niepełnosprawnościami jest Konwencja Praw Osób Niepełnosprawnych ONZ z 13 grudnia 2006 r., ratyfikowana przez Polskę w $2012 \mathrm{r}^{35}$. Zawiera ona przepisy zakazujące dyskryminowania osób niepełnosprawnych, nakazuje wprowadzenie rozwiązań adresowanych do tej grupy społecznej, ułatwiających jej korzystanie z praw i wolności w każdej sferze życia na równi z innymi osobami. Na przykład jej artykuł 19 dotyczy prowadzenia życia samodzielnie i przy włączeniu w społeczeństwo, artykuł 26 zobowiązuje państwa do rozwijania programów i usług w zakresie rehabilitacji, zdrowia, zatrudnienia, edukacji i usług socjalnych.

W dokumencie pt. „Europejska strategia w sprawie niepełnosprawności 2010-2020: Odnowione zobowiązanie do budowania Europy bez barier" zaproponowano działania mające ułatwić osiągnięcie celów wyznaczonych przez Konwencję. Między innymi ma to być: zapewnienie właściwego poziomu usług instytucjonalnych oraz środowiskowych systemów opieki poprzez wykorzystywanie funduszy strukturalnych, poprawę mobilności, dostępności i organizacji usług, w tym sportowych i kulturalnych ${ }^{36}$.

Jak starano się wykazać w tym opracowaniu, system wspierania zatrudnienia osób z niepełnosprawnościami wymaga zmian. Od wprowadzenia ustawy z $1991 \mathrm{r}$. podejmowano nowelizacje jego zapisów zbyt wiele razy. Wydaje się, że zarówno pracodawcy, pracownicy niepełnosprawni, jak i inni aktorzy rynku pracy nie ufają już tej regulacji. Może warto byłoby zastanowić się nad tym, czy nie jest to odpowiedni moment na skorzystanie z przykładu państw uzyskujących najlepsze wyniki w zakresie zatrudniania osób z niepełnosprawnościami, np. Irlandii, Szwajcarii, Norwegii i innych państw skandynawskich. W większości z nich nie ma systemu udziałowego, lecz zatrudnienie niepełnosprawnych jest częścią całej polityki zatrudnienia. Dostęp do zatrudnienia osób niepełnosprawnych na równi ze sprawnymi wynika z równości praw obywatelskich. Czy jest to możliwe w polskich warunkach? Prawdopodobnie należałoby wiele pracy włożyć $\mathrm{w}$ walkę z mitami i stereotypami na temat osób niepełnosprawnych, wciąż funkcjonujących w naszym społeczeństwie ${ }^{37}$. Zakaz dyskryminacji w zatrudnieniu i każdej innej sferze funkcjonowania społecznego wymaga istnienia jednoczesnego prawa dochodzenia go, czyli skutecznego wymiaru sprawiedliwości. W tym zakresie pozostaje chyba jeszcze wiele do zrobienia.

System zatrudnienia nie działa w próżni, jest ściśle powiązany z każdym elementem systemu zabezpieczenia społecznego, szczególnie ubezpieczenia społecznego i pomocy

35 Dz.U. z dnia 25 października 2012 r. poz. 1169.

${ }^{36}$ O. Kowalczyk, Jaka polityka..., s. 168.

${ }^{37} \mathrm{~W}$ interesujący sposób czyni to Stowarzyszenie Przyjaciół Integracji w wielu swoich przedsięwzięciach, np. poprzez książkę D. Grajewska, Fakty i mity o osobach z niepetnosprawnością, Warszawa 2009. 
społecznej. W ramach tego pierwszego pilnej reformy wymaga system rentowy od lat niedopasowany do nowego systemu emerytalnego. Zasady naliczania rent $\mathrm{z}$ tytułu niezdolności do pracy, pozostawione niezmienione po 1999 r., powodują, że prawdopodobnie coraz więcej rent nie będzie zastępowanych emeryturą po osiągnięciu przez rencistę wieku emerytalnego. Gdyby tak się stało, musiałyby one ulec radykalnemu zmniejszeniu, co z kolei wiązałoby się z koniecznością podnoszenia ich do poziomu minimalnej emerytury i zwiększonego wydatku z FUS ${ }^{38}$. Wydolność systemu rentowego nie jest zadowalająca: w 2013 r. wynosiła tylko 58\%, według prognoz ZUS w 2017 r. miała się poprawić do wysokości $62 \%{ }^{39}$.

Zmiany wymaga także system orzeczniczy. Istniejące dwa systemy orzekania o niepełnosprawności i o niezdolności do pracy - powodują wiele utrudnień dla ludzi z nich korzystających: powielanie orzeczeń, zwiększanie kosztów i zaciemnianie obrazu. Jednocześnie od lat oczekiwana reforma całej opieki długoterminowej, na przykład konieczność uporządkowania zasad jej finansowania, precyzyjniejsze określanie zasad dostępu do świadczeń, wymaga wprowadzenia nowego elementu orzekania o niesamodzielności, co prawdopodobnie spowoduje reformę całego tego systemu.

$\mathrm{Na}$ to, jak bardzo doświadczanie niepełnej sprawności wpływa na poziom i jakość życia w Polsce, zwracają uwagę autorzy Diagnozy Społecznej, którzy twierdzą, że niepełnosprawni to grupa społeczna najbardziej narażona na dyskryminację. Piszą oni:

Niepełnosprawni są w Polsce dyskryminowani obiektywnie na wiele sposobów, choćby ze względu na bariery architektoniczne zmuszające ich do pozostawania $\mathrm{w}$ domu. Zadziwiające jest zatem, że nie czują się dużo bardziej dyskryminowani od osób pełnosprawnych, zwłaszcza jeśli mają więcej niż 40 lat ${ }^{40}$.

Według Rzecznika Praw Obywatelskich osoba z niepełnosprawnością, która stała się ofiarą nierównego traktowania, nie dysponuje taką samą jak inni ochroną przed dyskryminacją. Rzecznik krytycznie ocenia także skuteczność środków przewidzianych do ochrony i przeciwdziałania naruszeniom zasady równego traktowania osób z niepełnosprawnościami ${ }^{41}$.

Niedawno podjęto kolejną próbę wyjścia naprzeciw potrzebom mniej sprawnej części naszego społeczeństwa. W 2016 r. premier polskiego rządu powołała specjalny Zespół do spraw Opracowania Rozwiązań w zakresie Poprawy Sytuacji Osób Niepełnosprawnych i Członków ich Rodzin, który ma wypracować nowe rozwiązania w zakresie poprawy sytuacji osób niepełnosprawnych i członków ich rodzin.

${ }^{38} \mathrm{O}$ trudnej sytuacji finansowej FUS, konieczności dotowania go z budżetu państwa można przeczytać w: K. Bielawska, Rola pozaskładkowych źródeł w finansowaniu świadczeń z ubezpieczenia społecznego wypłacanych z Funduszu Ubezpieczeń Społecznych, „Ubezpieczenia Społeczne. Teoria i praktyka” 2016, nr 2, s. $3-19$.

${ }^{39}$ Informacja o wynikach kontroli wykonania budżetu państwa w 2014 r....

$40 \mathrm{http}: / /$ www.diagnoza.com/pliki/raporty/Diagnoza_raport_2015.pdf (dostęp: 13 marca 2018).

${ }^{41}$ Realizacja przez Polskę zobowiązań wynikajacych $z$ konwencji o prawach osób niepetnosprawnych. Sprawozdanie Rzecznika Praw Obywatelskich 2012-2014, http://www.rpo.gov.pl (dostęp: 13 listopada 2017). 


\section{Bibliografia}

Barczyński A., Realne bariery wstrzymujące aktywizację zawodowa niepełnosprawnych, [w:] Społeczne korzyści zatrudniania osób niepetnosprawnych, red. A. Barczyński, KIGR, Warszawa 2008.

Bielawska K., Rola pozaskładkowych źródeł w finansowaniu świadczeń z ubezpieczenia społecznego wypłacanych z Funduszu Ubezpieczeń Społecznych, „Ubezpieczenia Społeczne. Teoria i praktyka” 2016, nr 2.

Ciaputa E., Król A., Warat M., Genderowy wymiar niepełnosprawności. Sytuacja kobiet z niepetnosprawnościami wzroku, ruchu, słuchu, [w:] Polscy niepetnosprawni. Od kompleksowej diagnozy do nowego modelu polityki społecznej, red. B. Gąciarz, S. Rudnicki, Wydawnictwo AGH, Kraków 2014.

Dostępność wsparcia środowiskowego dla osób starszych w perspektywie przedstawicieli gmin województwa dolnośląskiego. Analiza i zalecenia, Warszawa 2016, https://www.rpo.gov.pl/ (dostęp: 10 czerwca 2017).

Dziewięcka-Bokun L., Mielecki J., Wybrane problemy polityki społecznej, Wydawnictwo Uniwersytetu Wrocławskiego, Wrocław 1997, rozdz. 7.

Dz.U. nr 123, poz. 776 i Uchwała Sejmu Rzeczypospolitej Polskiej z dnia 1 sierpnia 1997 r. (M.P. z 1997 r. Nr 50. poz. 75.).

Garbat M., Zastosowanie modelu DMP w analizie rynku pracy osób z niepełnosprawnością, „Polityka Społeczna" 2013, nr 8.

Golinowska S., Zabezpieczenie społeczne osób niepełnosprawnych w Polsce i w innych krajach, MPiPS CASE, Warszawa 2001.

Grajewska D., Fakty i mity o osobach z niepetnosprawnością, INTEGRACJA, Warszawa 2009.

http://www.mpips.gov.pl.

http://www.niepełnosprawni.gov.pl.

http://www.pfron.gov.pl.

http://www.zus.gov.pl.

http://www.rpo.gov.pl.

Informacja o świadczeniach pieniężnych $z$ FUS oraz o niektórych świadczeniach zabezpieczenia społecznego w 2015 roku, http://www.zus.pl (dostęp: 30 listopada 2016).

Informacja o wynikach kontroli wykonania budżetu państwa w 2014 r. w części 73 - Zakład Ubezpieczeń Społecznych oraz wykonania planów finansowych: Funduszu Ubezpieczeń Społecznych, Funduszu Emerytur Pomostowych, Funduszu Rezerwy Demograficznej i planu finansowego Zakładu Ubezpieczeń Społecznych - państwowej osoby prawnej, Warszawa 2015, http://www.zus.pl (dostęp: 30 listopada 2016).

Informacja o wynikach kontroli. Skuteczność wybranych form aktywnego przeciwdziałania bezrobociu $w$ niektórych województwach w 2014 roku, http://www.nik.pl (dostęp: 21 lipca 2016).

Jaworski J., Praca dla osób niepetnosprawnych w zwalczaniu ich wykluczenia społecznego. Ocena polskiego systemu wspierania zatrudnienia osób niepełnosprawnych, IPiSS Opracowania PBZ, Warszawa 2009.

Kołaczek B., Proponowane kierunki zmian dotychczasowego systemu wsparcia zatrudnienia osób niepetnosprawnych, „Polityka Społeczna” 2014, nr 8.

Kowalczyk O., Jaka polityka społeczna wobec rodzin z osobami niepelnosprawnymi w Polsce?, „Prace Naukowe UE we Wrocławiu" 2016, nr 438.

Kowalczyk O., Rehabilitacja osób niepetnosprawnych - nowe rozwiązania, ORPHA, Wrocław 1993.

Kowalczyk O., Zatrudnienie i rehabilitacja zawodowa osób niepełnosprawnych w Polsce $w$ kontekście praw społecznych - wybrane zagadnienia, „Ubezpieczenia społeczne. Teoria i praktyka” 2015, nr 3.

Kryńska E., Pater K., Projekt. Zatrudnienie osób niepetnosprawnych. Perspektywy wzrostu, Warszawa 2013, s. 10, http://www.ipiss.com.pl (dostęp: 30 listopada 2016).

Księżopolski M., Wspólnie czy osobno. Rozważania o polityce społecznej, IPS Uniwersytet Warszawski, Warszawa 2013.

Marska-Dzioba N., Racjonalność wydatków publicznych przeznaczonych na integracjęosób niepetnosprawnych w Polsce, Uniwersytet Szczeciński, Szczecin 2013.

Oczki J., Nierówności na rynku pracy w Polsce, [w:] Nierówności społeczne w Polsce, red. B. Kłos, J. Szymańczak, Wydawnictwo Sejmowe, Warszawa 2014. 
Opiekunowie rodzinni osób starszych - problemy, potrzeby, wyzwania dla polityki społecznej. Raport z badania, oprac. M. Szlązak, A. Piłat, J. Sarata, Regionalny Ośrodek Polityki Społecznej, Kraków 2015.

Petelczyc J., Roicka P., Wyniki badań zrealizowanych metoda IDI w powiatowych urzędach pracy, [w:] Rehabilitacja zawodowa. Stan aktualny i proponowane zmiany, red. G. Uścińska, A. Wilmowska-Pietruszyńska, IPiSS, Warszawa 2014.

Polityka społeczna, red. A. Rajkiewicz, PWN, Warszawa 1979.

Raport końcowy w ramach badania pt. Badanie realizacji przez samorządy powiatowe zadań ustawowych na rzecz osób niepetnosprawnych, http://www. pfron.gov.pl (dostęp: 10 czerwca 2017).

Realizacja przez Polskę zobowiązań wynikających z konwencji o prawach osób niepetnosprawnych. Sprawozdanie Rzecznika Praw Obywatelskich 2012-2014, http://www.rpo.gov.pl (dostęp: 13 listopada 2017).

Samorzad terytorialny. Teksty jednolite, Wydawnictwo CH Beck, Warszawa 1999.

System wsparcia osób starszych w środowisku zamieszkania. Przegląd sytuacji. Propozycja modelu, red. B. Szatur-Jaworska, P. Błędowski, Warszawa 2016, http://www.rpo.gov.pl (dostęp: 10 czerwca 2017).

Świadczenie pomocy osobom starszym przez gminy i powiaty, https://www.nik.gov.pl/aktualnosci/niko-swiadczeniu-pomocy-osobom-starszym.html (dostęp: 15 maja 2016).

Ubóstwo w Polsce w latach 2013-2014, GUS, Warszawa 2015, https://stat.gov.pl. Ubostwo_w_polsce_w_latach_2013-2014.pdf.

Ustawa z dnia 9 maja 1991 r. o zatrudnieniu i rehabilitacji zawodowej osób niepełnosprawnych (Dz.U. z 1991 r. Nr 46).

Ustawa o emeryturach i rentach z FUS z 1998 r. (Dz.U. Nr 62, poz. 1118).

Ustawa o organizacji i finansowaniu ubezpieczeń społecznych (Dz.U. Nr 100, poz. 46).

Ustawa z dnia 28 listopada 2003 r. o świadczeniach rodzinnych, Dz.U. z 2015 r. poz. 114 z późn. zm.

Ustawa z dnia 4 kwietnia 2014 r. o ustaleniu i wypłacie zasiłków dla opiekunów, Dz.U. z 2014 r. poz. 567.

Wydatki na świadczenia z ubezpieczenia społecznego związane z niezdolnościa do pracy w 2013 r., http:// www.zus.pl (dostęp: 30 listopada 2016).

\section{Quarter-century of reform in the social security system for the disabled in Poland — selected aspects}

Keywords: disability, social security, employment, care services

\section{Summary}

Social policy regarding people with disabilities has been transformed over the past 25 years. The greatest change is seen in the social security system for this social group, including the area of jurisprudence and the availability of funding and services. The system of supported employment has also been reformed. This paper analyzes the effects of instruments studying employment, highlights selected aspects of the disability pension system that is expected to be adjusted under the new pension system, and discusses some aspects of long-term care - benefits available to dependent family members. The aim of the article is to try to assess the reforms undertaken in the context of the whole-life situation of people with disabilities. 